Research Report No. 30/2010

\title{
The Greatest Tragedy of All: Regulating the Atmosphere in a Climate of Indecision
}

Donal R. Hamilton

Follow this and additional works at: http://digitalcommons.osgoode.yorku.ca/clpe

\section{Recommended Citation}

Hamilton, Donal R., "The Greatest Tragedy of All: Regulating the Atmosphere in a Climate of Indecision" (2010). Comparative Research in Law \& Political Economy. Research Paper No. 30/2010.

http://digitalcommons.osgoode.yorku.ca/clpe/97 


\section{OSGOODE}

OSGOODE HALL LAW SCHOOL Y O R K N I V ER S I T Y

\section{OSGOODE HALL LAW SCHOOL Comparative Research in Law \& Political Economy}

\section{RESEARCH PAPER SERIES \\ Research Paper No. 30/2010}

\section{Editors:}

Peer Zumbansen (Osgoode Hall Law School, Toronto, Director, Comparative Research in Law and Political Economy)

John W. Cioffi (University of California at Riverside)

Lisa Philipps (Osgoode Hall Law School, Associate Dean Research)

Nassim Nasser (Osgoode Hall Law School, Toronto, Production Editor)

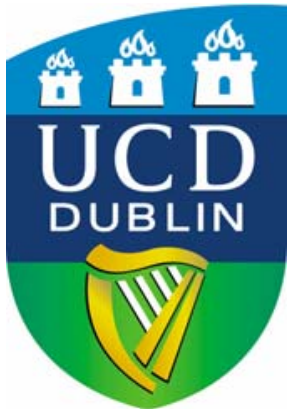

\section{UCD WORKING PAPERS IN}

LAW, CRIMIN OLOGY \&

SOCIO-LEGAL STUDIES

Research Paper No. 33/2010

Editors:

Blanaid Clarke, Associate Professor in Corporate Law and Director of Research, UCD School of Law

Colin Scott, Professor of EU Regulation and Governance and Director, UCD Centre for Regulation and Governance, University College Dublin

\title{
The Greatest Tragedy of All: Regulating the Atmosphere in a Climate of Indecision
}

\author{
Donal R. Hamilton
}


CLPE Research Paper 30/2010

Vol. 06 No. 07 (2010)

UCD Research Paper 33/2010

\title{
The Greatest Tragedy of All: Regulating the Atmosphere in a Climate of Indecision
}

\begin{abstract}
Climate change is a serious challenge to our planet. The point of no return will be upon us in 2014 and we are yet to regulate the emission of greenhouse gas. Failure to reach agreement at the 2009 UN Climate Change Summit in Copenhagen highlighted the difficulties we face in regulating use of the ultimate common pool recourse: our atmosphere. Surrounding these difficulties is the specter of an ideological debate between 'public' and 'private' that is as contentious as ever, and central to this contest is the problem of the free rider. This author will argue that in the long run, a global approach to climate change combining elements of privatization and public control is desirable. This is however proving difficult to achieve. It is contended that in the short term, the polycentric approach advocated by Elinor Ostrom is a desirable alternative and would be of benefit in developing proposals for a long-term solution.
\end{abstract}

Key words: Climate Change, Regulation, Governance.

JEL classification: K 20, K 32, Q 54

Donal R. Hamilton

BCL, LLM (Commercial Law) Candidate

UCD School of Law

Email: donal.hamilton@ucdconnect.ie 


\title{
The Greatest Tragedy of All: Regulating the Atmosphere in a Climate of Indecision
}

\author{
Donal R. Hamilton ${ }^{*}$
}

As temperatures rise due to the emission of greenhouse gasses into the atmosphere, we are confronted with a grave threat to the world, as we know it. 2014 has been identified as the time when the damage done to our planet will be irreparable (Mallon et al. 2009). It is the point of no return. Though world leaders agree that regulation is needed to ensure the sustainability of this global commons, there is little agreement as to how this should be achieved. Time ticks by, attempts to regulate fail and we remain without a plan of action ${ }^{1}$. This author will analyze the various strategies that can be utilized in regulating the atmosphere and propose an alternative way forward. It is hoped that regulators will take heed to the already sounding warning bells, and devise a regulatory response to the global climate crisis before irreparable harm is done to our planet.

The climate commons issue is highly relevant in the wake of the failed Copenhagen summit of 2009. The 2009 summit attempted to address the climate commons issue on a worldwide scale but ultimately failed due to a lack of political will and an inability by participants to agree on the regulatory mechanism to be used ${ }^{2}$. The mechanism proposed the summit involved a privatized emissions trading system, and was met with stiff resistance by socialist states including Venezuala, Bolivia, and $\mathrm{Cuba}^{3}$. The atmosphere is the ultimate example of a common pool resource, which is a type of resource that is notoriously difficult to regulate due to the existence of a free rider problem (See: Hardin 1968, Ostrom 1990). The Copenhagen failure indicates that we are far from reaching a worldwide consensus on the fundamental question of whether a 'public' or 'private' regulatory response is the most efficient way to deal with this global common pool resource problem. This 'public' versus 'private' debate is central to the body of literature on common pool resource theory, a body that has been greatly enhanced by winner of the 2009 Nobel Prize for economics, Elinor Ostrom.

Due to the problem of the free rider, there is difficulty in determining which institution is best suited to regulate common pools of resources (Ostrom 1990; p. 6), and it is submitted that this is a major problem in regulating the atmosphere. There are competing views on the issue. Some, such as Ophuls (1973), Heilbroner (1974) and Ehrenfield (1972) argue in favour of a public control approach while others such as Smith (1981) and Ostrom (1990) argue that privatization and self-governance respectively are more appropriate. Prior to the Copenhagen summit, Ostrom advocated a polycentric regulatory approach to the climate

\footnotetext{
${ }^{*}$ BCL, LLM (Commercial Law) Candidate, UCD School of Law. Email: donal.hamilton@ucdconnect.ie

${ }^{1}$ E.g. The UN Climate Change Summit in Copenhagen, 2009.

2 See: Harvey et al, Copenhagen: A Discordant Accord, Financial Times, 20 Dec 2009 and www.ufppc.org for analysis.

${ }^{3}$ Ibid
} 
change issue involving regulation on multiple levels (Ostrom 2009). It is submitted that this approach could be used to avoid the 'public' versus 'private' debate and effectively allow regulation to proceed without global consensus. It will be argued however that such an approach is undesirable in the long term due to the possibility of regulatory arbitrage.

This author contends that if we are to have a truly global climate change policy in the long term, an alternative approach is needed. Such an alternative must address the theoretical concerns many have with the private market based regime, which is currently the dominant approach. It is submitted that a hybrid approach could be developed along the lines of a public-private partnership and through this, both sides of the iron curtain can be appeased.

\section{THE TROUBLE WITH CPRS}

A common pool resource (CPR) can be described as a shared finite resource to which it is difficult to limit access. Examples of such resources include fresh water, fisheries and the atmosphere. Aristotle once said 'what is common to the greatest number has the least care bestowed upon it' (Politics, Book II, Ch. 3). More recently, Clark has noted that when a number of people have access to a CPR, the number of units withdrawn will be greater than optimal (1976). Consequently an examination of the problems associated with CPRs in general is necessary in order to fully understand the challenges that confront climate change regulators. In particular, there are three dilemmas that contribute towards a general free-rider problem, making CPRs particularly difficult to regulate (Ostrom 1990, pp. 2-7). Adam Smith's invisible hand theory plays an important part in these dilemmas as they all operate under the assumption that individuals pursue only their own gain (Smith 1937). The dilemmas in question are the tragedy of the commons, the prisoner's dilemma, and the collective action issue.

In his 1968 article, Garrett Hardin posited that free access to a CPR inevitably leads to its destruction. He describes how this tragedy of the commons operates using the example of a group of herdsmen operating in a common pasture. Each herdsman naturally seeks to maximize his gain. A herdsman will gain positive utility of +1 if he adds an extra animal to his herd while the negative utility that arises due to overgrazing is merely a fraction of 1 as the commons is shared by all. Consequently the rational herdsman will add another animal as he has more to gain than he has to lose. As this continues, therein lies the tragedy as the pasture will degrade and become useless to all of the herdsmen. Hardin posited that freedom of the commons would bring ruin to us all $(1968$, p. 2$)$.

The tragedy of the commons suggests that individuals have little to gain from acting in the interests of preserving the commons. The herder example is magnified and complicated to a great extent in the context of climate change as the effects of climate change do not manifest themselves with equal force in all parts of the world. The emission of $\mathrm{CO} 2$ by the Scherer coal plant in Georgia for example, does little to the immediate environment, but has serious consequences for parts of the world that are hyper-sensitive to rising sea levels that 
are a consequence of global warming ${ }^{4}$. The sheer size of the atmosphere as a CPR renders minimal the incentive for greenhouse gas emitters not to engage in pollution. It is therefore contended that while there is at least some incentive for the herders who obtain tangible benefit from preserving their common pasture, there is no such incentive for greenhouse gas emitters.

The same problem can be interpreted as a prisoner's dilemma (See: Luca \& Raiffa 1957, p. 95). Applying this game to the herder example, the object is to maximize profits for all involved (Dawes 1973, Ostrom 1990, p. 3). There are two possible strategies that may be employed by a herder. Either he can cooperate and graze the optimal number of animals on the commons, or he can defect and graze as many as possible. In a game of two herders, if both cooperate they will obtain 10 units of profit. If one defects, he will obtain 11 units and the other (the "sucker") will obtain 9 units. If both defect however, they will both receive no profit. While cooperation is the best option for both herders, it is not the best individual strategy. In addition, if herder A cooperates and herder B defects, A is a sucker. We are left with a dilemma. Do we cooperate? Or do we defect?

A third dilemma can be identified that exists in a CPR situation; the difficulty of getting individuals to act in their joint welfare (Olson 1965). While traditional opinion posited that individuals will act in the interests of those with whom they have a common interest (Bentley 1949), Olson argued that unless there is a small number of concerned individuals or an element of coercion, 'rational self-interested individuals will not act to achieve their common or group interests' $(1965$, p.2). This dilemma is proving particularly difficult to overcome in the climate change debate. Olson's thesis is proving true as resource users continue to pollute the atmosphere with greenhouse gasses, despite the damaging effect it has on the global commons.

Ostrom isolates the free-rider problem as central to these dilemmas (1990, p. 6). Individuals, who cannot be excluded from the resource and are without incentive to act in the common interest, may be inclined to piggyback on the efforts of other users. The free-rider problem can dominate the decision making process of rational commons users and result in a suboptimal course of action being taken. According to Ostrom, this problem can be used to explain why rational individuals can sometimes make irrational decisions. This problem is a major concern in the climate change debate. The fear that some countries will not fulfill their obligations while obtaining the full benefit of clean air militates against global regulation of the atmosphere. While the decision to free ride offends morality and one's sense of justice (Ittner \& Ohl 2005), it seems unlikely that moral pressure will be enough considering the economic implications of reducing emissions. If climate change is to be curbed, as it must, it is submitted that prevention of free riding must be at the nucleus of the regulatory regime.

\footnotetext{
4 The Maldives are on average $1 \mathrm{~m}$ above sea level and thus at risk due to rising sea levels (http://news.bbc.co.uk/2/hi/south_asia/3930765.stm). The Scherer plant is the biggest CO2 emitters in the USA (see: http://www.eurekalert.org/pub_releases/2007-11/cfgd-crc111207.php).
} 


\section{The Hidden PAW, Carbon Credits and Self-Governance}

CPR management theory is at the heart of an ideological debate between the advocates of state control and the advocates of free markets, a debate that has been active since February $1848^{5}$. On one side, it is argued that the only way to deal with the prisoner's dilemma of a CPR is for the state to intervene and impose restrictions on its users (Ophels 1973, Heilbronner 1974). The countervailing argument put forward is that the optimal way to preserve a commons is to put it into private ownership (Smith 1981). A third model argues that centralization or privatization is not needed to solve CPR problems, rather community-devised self-governing common property arrangements can be used to break the tragedy of the commons (Ostrom 1991). It is submitted that a middle ground must be found between these zealously guarded extremes if a global regulatory regime is to be successful.

The classic debate between 'market' and 'state' is well illustrated in Lochner $v$ New York when the US Supreme Court obliquely confronted the issue ${ }^{6}$. In this case, a New York statute prevented employers from allowing their bakers to work more than 60 hours per week. The issue was whether the law could interfere with the personal liberty of the baker to work the hours he has contracted to work. For the majority, Peckham J came down in favour of the free market and held that there was an unreasonable and arbitrary interference with the baker's right to liberty. The restriction was not beneficial on health grounds therefore the state had no right to interfere with his freedom to contract. Harlan J on the other hand dissented arguing that the state could be justified in regulating bakers working hours as it fulfilled a legitimate health objective. Holmes J dissented arguing that it is not the place of the courts to decide cases on the grounds of a particular economic theory citing many examples of state interference with private affairs. Despite its age, the decision in Lochner is a useful introduction to the modern CPR management debate as it highlights the lack of agreement regarding the role of the state in regulating our affairs. The diversity of opinion evinced in Lochner is precisely why use of the atmosphere is proving difficult to regulate.

At one end of the spectrum, Heilbroner argued that iron government was needed to successfully regulate common resources (1974). A more levelheaded Ophuls argued that the hidden paw of the state is needed to coerce resource users into compliance due to the tragedy of the commons (1973 p. 228). Further proponents of state intervention argue that "CPRs require pubic control if economic efficiency is to result" (Carruthers \& Stoner 1981, p. 29). Essentially this view advocates the establishment of a centralized agency to restrict access to resources, monitor compliance and punish defectors.

Ostrom criticizes the centralized agency approach for a number of reasons (1991 p. 9). She argues that the optimal equilibrium achieved following this model depends on the accuracy of information, monitoring capabilities, sanctioning reliability and zero transaction costs. In

\footnotetext{
${ }^{5}$ Marx \& Engels' The Communist Manifesto was published.

${ }^{6} 198$ U.S. 45 (1905)
} 
particular she argues that the equilibrium achieved through this method is delicate and the centralized agency will need complete information in order to be successful. In the context of climate change, an example of a centralized regime is found in a proposal to attach quantitative limits to emissions that are supervised and enforced by regulatory oversight (Engel \& Saleska 2005, p. 191).

In contrast, some believe that state intervention is not the appropriate way to deal with CPR problems, rather a privatization of the commons is necessary whereby private property rights are assigned to the users (Demsetz 1967, Smith 1981, Welsh 1983, Boyle 2003). Private property rights would induce the users to take greater care of the commons due to the elimination of the Hardin dilemma. Detriment to the commons from adding each animal above the sustainable level would no longer be spread among commons users, rather it would now be felt entirely by the herder. By assigning these rights, it is hoped that the Aristotle's predicament can be avoided.

Privatization has been criticized as inapplicable to certain types of commons. Clark states that this regulatory method is wholly inappropriate regarding fishery protection where the assignment of property rights is "virtually out of the question" (Clark 1980, p. 117). In the context of open access fisheries such as the high seas (excluding inshore bays where property rights are possible), it is impossible to assign property rights due to the lack of homogeneity of the resource. A plentiful fishing ground one year may be barren the year after, making it ineffectual to assign rights to a particular ground. Clark asserts that common ownership is the fundamental fact in fishery management (1980, p. 117). It is submitted that common ownership is also a fundamental fact regarding our atmosphere however unlike fisheries, the atmosphere is homogenous and therefore could be regulated by assigning the same property rights to all users of this global resource.

Proposals for a 'private' regime can seem quite drastic. Dawson has argued that government intervention regarding climate change should be abolished as governments lack the knowledge needed to successfully regulate (2009, p. 57-62). He argues that additional property rights are not needed; instead our existing property rights should be properly protected. He proposes that if a person whose land has been damaged by deforestation could sue a fossil fuel emitter for the damage done to this property, the courts could use precedent to devise a privatized policy to guide emitters. This author posits that Dawson's suggestion is wholly unpractical. Climate change is a global problem. There are 193 countries in the United Nations, each with its own court system, therefore such a regime would inevitably lead to inconsistency and some countries may become emissions havens, facilitating regulatory arbitrage. Such a regime therefore does not answer our problem.

A more levelheaded market based approach in the form of cap and trade (emissions trading) was suggested at the Copenhagen summit ${ }^{7}$. Cap and trade involves a price being set for carbon allowing it to be used as a tradable commodity (Driesen 1998, p. 2). If polluters want

\footnotetext{
${ }^{7}$ See: Proposal of the European Commission for the establishment of a global carbon market. Towards a comprehensive climate change agreement in Copenhagen

$\operatorname{COM}(2009) 39$ final
} 
to increase their output of greenhouse gasses, they will have to purchase carbon credits from polluters who are not using all of their assigned credits. Theoretically, this creates an incentive for polluters to reduce their emissions, as they will be able to sell the credits they generate. It is submitted that such a regime could be gamed by wealthy countries that could effectively buy their way out of their carbon obligations. Driesen has been critical of the cap and trade approach, describing it as a cheap fix (1998). He argues that allowing polluters to purchase credits reduces the incentive to innovate and obstructs democratic accountability. State control in the form of quantitative trading limits must be imposed in order to prevent the creation of pollution hot spots that would arise under unrestrained cap and trade. In the light of this criticism, one must conclude that the answer to our problem is not with an entirely privatized regime.

The Kyoto Protocol currently in force is a mixture of both the centralization and privatization

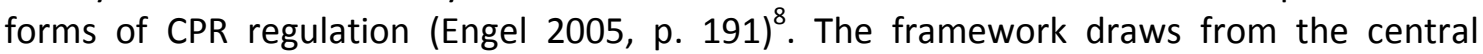
control school of thought by imposing binding limits on signatory countries ${ }^{9}$. In addition, private market advocates are appeased through the establishment of an emissions trading mechanism ${ }^{10}$. Under this regime, the emissions limits assigned to each signatory country can be met through the trade of emissions allowances or by financing emission reduction ${ }^{11}$. The Kyoto framework does not however, have global support with one notable absence being the USA. The lack of global support is, in the opinion of the author, a denial of reality. Defecting nations justify their decision on the ground that Kyoto is overly damaging to their economy (See: Grubb 1993). In reality, this author submits that a drop in GDP of approximately $0.5 \%$ to $3 \%$ is a small price to pay to ensure the sustainability of our planet (See: Shogren 1999, p. 11).

The third alternative revolves around the concept of self-governance as extensively studied by Ostrom (1991). Her work showed how CPR problems can be managed successfully by the parties that use them and without the need for privatization or central control. She is highly critical of the belief that one or other of these solutions is the only way to solve CPR problems and notes that for either to be applied, change must come from outside and be imposed on the individuals concerned. She argues that forcing new institutional arrangements on resource users at huge cost for the most part does not work. An example found in Port Lameron Nova Scotia illustrates her point. Here local fishermen devised a successful system that ensured sustainability of the resource and provided them with a living. However, the imposition of a centralized licensing regime has resulted in severe resource deterioration (Ostrom 1990, p. 177). Ostrom argues that most successful CPR regimes involve a mixture of 'public' and 'private' elements rather than the arbitrary imposition of one or the other. She concludes that there is not just one way to solve CPR problems rather there are many solutions, which in turn are circumstance dependant.

\footnotetext{
${ }^{8}$ Kyoto Protocol to the United Nations Framework Convention on Climate Change, Dec. 10, 1997, 37 I.L.M. 22 (1998)

${ }^{9}$ Ibid, at Art 3(1)

${ }^{10} \mathrm{Ibid}$, at Art 17

${ }^{11}$ Ibid \& Art 3(3)
} 
Ostrom identifies a number of design principles that are present in long enduring CPR institutions (1991, p. 90). In particular, she notes that the boundaries of a CPR must be clearly defined in order for self-governance to be effective. It is submitted that a fundamental characteristic of the atmosphere is that it can be openly accessed, and this is at odds with the boundary requirement. Without clearly defined boundaries, resource users who implement sustainability measures will find that users who have not contributed are benefitting from their efforts. This brings us back to our prisoner's dilemma: Do we cooperate? Or do we defect? Consequently this author contends that the use of a selfgovernance regulatory regime in a commons as vast and open as the atmosphere will leave us with the same free-rider problem as when we started.

\section{Proposals for Part DEUX}

The dominant approach in the lead up to the 2009 summit effectively involved the privatization of the atmosphere through the use of emissions trading ${ }^{12}$. This approach would see a price being attached to greenhouse gasses and make them a tradable commodity. As discussed above, cap and trade systems such as this can be criticized as they effectively allow countries to purchase permits to pollute. This is inherently unfair as it allows wealthy countries to buy their way out of their carbon commitments. Failure to agree to such a scheme highlights the legitimate difficulties many have with an outright privatization regime. With a further UN Climate Change Conference in Cancun Mexico scheduled for 2010, it is submitted that the concerns many countries have with a private market regime need to be taken seriously and an alternative approach is needed in order to move forward.

While we are urgently in need of a long-term global solution, the Copenhagen failure indicates that we are much farther away from this solution than we would hope. Nevertheless, as Churchill has aptly stated, "it's not enough that we do our best; sometimes we have to do what is required" (Goodwin 2007). Since global warming is a global problem, the author contends that a worldwide climate change strategy is desirable. With efforts to achieve this utopia in unknown territory, it is submitted that in the short-term at least, we may have to settle for second best. This author posits that international bodies should consider Ostrom's suggestion of a polycentric approach to climate change regulation. Such a regime could plausibly be used as a short-term gap-filler until the coveted global approach can be agreed.

Prior to the Copenhagen summit, Ostrom argued that a polycentric regulatory strategy should be adopted rather than the currently favoured monocentric hierarchy (2009). Ostrom argues that a monocentric approach to climate regulation will be unsuccessful as it will not be able to generate sufficient levels of trust among resource users. This returns us to the classic collective action problem discussed above, which highlights the difficulty in making individuals act for the benefit of the group. She believes that such approaches are

\footnotetext{
${ }^{12}$ Supra note 7
} 
prone to free-rider problems as they can be easily 'gamed' by resource users (2009, p. 27). The Clean Development Mechanism under the Kyoto agreement for example can be 'gamed' in a way that raises resource prices and encourages exploitation (Sovacool \& Brown 2009). Ostrom states that due to the collective action problems that exist in governing use of the atmosphere, efforts to regulate should operate on multiple scales and levels involving regional, national, and supra-national regulation (2009, p. 32). She argues that such an approach reduces opportunism by resource users, acknowledging that no institutional arrangement will ever totally eliminate this problem (2009, p. 32).

It is submitted that the polycentric approach could be used to create a neutral approach and avoid the ideological 'public' versus 'private' conundrum. By delegating the method of achieving emissions reductions to individual states, a global consensus regarding the way we address the issue is unnecessary. Countries could impose a centralized regime if they so wish, while others may choose to adopt a privatized system. The choice is up to them, so long as they reach their targets. Here however a specter of public control appears. Targets must unavoidably be set and enforced by a supra-national administrative authority. It is submitted that key to the neutrality of this approach is that the supra-national enforcement authority is administrative only, and merely imposes pre-determined graduated sanctions. With these restrictions, the author contends that this specter will not offend ardent privatization advocates. The downside of a polycentric approach lies with the inconsistency that inevitably arises. As with Dawson's privatization approach, discussed above, the polycentric approach raises the possibility of regulatory arbitrage, as greenhouse gas emitters will be attracted to areas with the most lax emissions rules. Consequently, it is submitted that this approach is not appropriate as a long-term solution.

This approach would be highly beneficial in the short-term however, allowing various methods to be tried and tested. Ostrom (2009) notes that polycentricism would encourage regulatory experimentation due to the ability of individual regulatory centers to devise their own rules. The success of a particular regime employed in one centre could then be accurately compared with the regime employed in another in order to ascertain which is more efficient. The obvious benefit is that this approach would allow for the development and assessment of alternative regulatory systems on a micro scale rather than taking a leap of faith and implementing them globally. It is submitted that the adoption of polycentrism would result in the identification of numerous alternatives to 'public' or 'private' regulation and would be a useful tool in devising a long-term solution.

It is contended that for a global problem like climate change, any long-term solution should ideally be implemented globally. Indeed, this proposition is nothing new; it is merely a reiteration of the opinion taken by numerous scholars in the past decade (see: Stavins 1997; Weiner 2007). But as Copenhagen illustrates, this is a difficult objective to achieve. It is submitted that in order to come closer to a long-term solution, a regime must be devised bringing together elements of both central control and the private market and advocates at both extremes must accept that one cannot exist without the other.

Karl Polanyi (1957, p. 59-70) investigated the origin and evolution of the 'market' as an institution, and reasons that it was in fact public control that created the market, and public control that keeps it in check through competition rules. 'Market' and 'state', he argues, are 
inextricably linked. In addition, Ostrom (1991, p. 15) states that the market itself is a public good, and cannot exist without the public institutions that support it. She notes that public and private institutions are frequently woven together and do not exist in isolated worlds. From this analysis, one must take the view that in the long term, the appropriate regulatory strategy for climate change will not be found at the extremes of the debate rather it will be found at the point where both views meet. The answer will be found in a hybrid.

The author contends that the hybrid approach of the Kyoto2 proposal should be seriously considered as a long-term answer (Tickell 2008). According to this proposal, the primary mechanism will be a pollution permit scheme based on the market system due to its efficiency in allocating resources. Essentially, firms that wish to extract resources will have to purchase these permits, which will be tightly restricted and linked to climate science recommendations. The income generated from sale of these permits will go into a fund, which will be used to fund environmental projects. The system also acknowledges a place for centralized regulation, which can be used to constrain greenhouse gas emissions and rectify specific market failures.

By adopting a hybrid approach like Kyoto2, it is submitted that the tragedy identified in traditional CPR theory can be mitigated. The problem prisoner's dilemma, discussed above, would continue to play a role in a hybrid approach though central control would be crucial in addressing this. Central control could be used to induce participants to cooperate with the regime rather than allow them to defect. Thus, the state will be used to ensure compliance with the rules of the market. As identified by Polanyi (1957), under the Kyoto2 proposal the market and the state are inextricably linked. It is submitted that such a regime is the optimal means to resolving the climate crisis in the long run.

\section{CONCLUSION}

Climate change is the greatest challenge facing our planet since the ice age and tragic consequences will ensue if mankind does not take the initiative and address the problem. The invisible hand however is stymieing our response. This author contends that in order to ensure the sustainability of our ultimate CPR, the regulatory response chosen must address the natural prisoner's dilemma that will arise. It is submitted that the success or failure in addressing this issue will be the difference between victory and calamity.

How we regulate is the subject of a contentious ideological debate that hampers our progress on the issue. A cold war exists between advocates of a market-based approach to climate regulation and advocates of a central control based approach. It is submitted that any long-term regulatory approach will require concessions on both sides of the debate, as a compromise will clearly have to be reached. This author contends that the most desirable mechanism currently offered is the hybrid approach found in the Kyoto 2 proposal (Tickell 2008) as it strikes a fair balance between the 'public' and 'private' regulatory theories.

The Copenhagen failure highlights the difficulty in achieving agreement as to the method of climate regulation. Consequently the author contends that until a global approach can be settled, the polycentric approach suggested by Ostrom (2009) could be useful. Through this approach, the contentious 'public' versus 'private' debate can be avoided, as consensus 
between countries regarding the method of emissions reduction is not necessary. Regulatory experimentation is another benefit of this approach, as it will identify successful alternatives that could be developed into a global strategy. Though free riding is still a problem, it is submitted that the polycentric approach could be a valuable mechanism in addressing the problem until a global strategy is agreed.

This CPR problem is urgent. Within five years, unless we establish and enforce regulations for a sustainable atmosphere, we will reach the point of no return (Mallon, et al. 2009). Pages will continue to be filled on the subject, and protests will continue to rage as a climate of indecision ravages our atmosphere. It is without doubt that unless the fundamental theoretical conflict between the 'public' and 'private' theories of regulation is resolved, a worldwide regulatory approach will continue to be untenable. Notwithstanding this conflict, it is clear that swift action is needed. It is therefore submitted that the polycentric approach should be adopted, as it will temporarily avoid this debate. And most importantly, buy us valuable time. 


\section{BIBLIOGRAPHY}

Bentley, A. (1949) The Process of Government. Evanston, Illinois: Principia Press.

Boyle, J. (2003) 'The Second Enclosure Movement and the Construction of the Public Domain', 66 LAW \& CONTEMP. PROB. 33, pp. 35-36

Carruthers, I. \& Stoner, R. (1981) 'Economic Aspects and Policy Issues in Groundwater Development'. World Bank staff working paper No. 496, Washington, D.C.

Clark, C. (1976) Mathematical Bioeconomics. New York: Wiley.

Clark, C. (1980) 'Restricted Access to Common-Property Fishery Resources: A GameTheoretic Analysis'. In Dynaic Optimization and Mathematical Economics, ed. P. Liu, pp. 11732. New York: Plenum Press.

Dawes, R. (1973) 'The Commons Dilemma Game: An N-Person Mixed-Motive Game with a Dominating Strategy for Defection'. ORI Research Bulletin 13, pp. 1-12

Dawson, G. (2009) 'Privatizing Climate Policy', Economic Affairs 29(3), pp. 57-62.

Demsetz, H. (1967) 'Toward a Theory of Property Rights'. American Economic Review 62, pp. 347-59.

Driesen, D. (1998) 'Free Lunch or Cheap Fix? The Emissions Trading Idea and the Climate Change Convention', 26 B. C. ENVTL. AFF. L. REV. 1, 34.

Ehrenfield, D. (1972) Conserving Life on Earth. Oxford University Press.

Engel, K. \& Saleska, R. (2005) 'Subglobal Regulation of the Global Commons: The Case of Climate Change'. Ecology Law Quarterly 32(2), pp. 183-233

Goodwin, (2007) The Forbes Book of Business Quotations, Black Dog Publishing, p. 168

Grubb, M. et al., (1993) 'The Costs of Limiting Fossil-Fuel CO2 Emissions: A Survey and Analysis', Annual Review of Energy and the Environment 18, pp. 397-478.

Hardin, G. (1968) 'The Tragedy of the Commons' 162 Science, pp. 1243-1248

Heilbroner, R. (1974) An Enquiry into the Human Prospect. New York: Norton.

Ittner, H. \& Ohl, C. (2005) 'Playing fair within climate protection policy? - Bringing together psychological and economic methods' IACM $18^{\text {th }}$ Annual Conference, available at www.ssrn.com

Luca, D. \& Raiffa H. (1957) Games and Decisions: Introduction and Critical Survey. New York: Wiley

Mallon, K. et al, (2009) 'Climate Solutions 2: Low Carbon Industrialization'. Climate Risk. 
Available at www.climaterisk.com.au

Marx, K. \& Engels, F. (1848) The Communist Manifesto. London: Frederick Engels

Olson, M. (1965) The Logic of Collective Action. Public Goods and the Theory of Groups. Cambridge, Massachusetts: Harvard University Press

Ophuls, W. (1973) 'Leviathan or Oblivion'. In Toward a Steady State Economy, ed. H. E. Daly, pp. 215-30. San Francisco: Freeman

Ostrom, E. (1990) Governing the Commons: The Evolution of Institutions for Collective Action. New York: Cambridge University Press.

Ostrom, E. (2009) 'A Polycentric Approach for Coping with Climate Change', Policy Research Working Paper No. 5095. Background paper to the 2010 World Development Report. Washington, DC: The World Bank.

Polanyi, K. (1957), The Great Transformation, Boston: Beacon Press [1944]

Shogren, J. (1999) 'The Benefits and Costs of Kyoto', FEEM Working paper No. 44-99, available at www.ssrn.com

Smith, A. (1776) An Inquiry into the Nature and Causes of The Wealth of Nations, Book IV, Ch. II, Para. IX

Smith R. (1981) 'Resolving the Tragedy of the Commons by Creating Private Property Rights in Wildlife'. CATO Journal 1, pp. 439-68.

Sovacool, Benjamin K., and Marilyn A. Brown. (2009) "Scaling the Policy Response to Climate Change." Policy and Society 27(4), pp. 317- 28.

Stavins, R. (1997) "Policy Instruments for Climate Change: How Can National Governments Address a Global Problem?" University of Chicago Legal Forum, volume 1997: Rethinking Environmental Protection for the 21st Century, 293-329.

Tickell, O. (2008) Kyoto2: How to manage the Global Greenhouse, Zedbooks Welsh, W. (1983) 'The Political Feasibility of Full Ownership Property Rights: The Cases of Pollution and Fisheries'. Policy Sciences 16, pp. 165-80

Wiener, J. (2007) 'Think Globally, Act Globally: The Limits of Local Climate Policies.' University of Pennsylvania Law Review 155, pp. 1961-79. 